\title{
COMPARATIVE LEAF MORPHO-ANATOMICAL STUDIES OF TWO SOUTH AMERICAN SPECIES OF CARDIOSPERMUM (SAPINDACEAE) WITH SPECIAL REFERENCE TO ADAXIAL DOMATIA
}

\author{
STELLA MARIS SOLÍS \& MARIA SILVIA FERRUCCI \\ Instituto de Botánica del Nordeste (UNNE-CONICET), C.C. 209, 3400 Corrientes, Argentina \\ e-mail: msferrucci@yahoo.com.ar
}

SUMMARY

\begin{abstract}
Morphological and anatomical studies of leaves of two closely related Cardiospermum species from South America, C. procumbens and C. pterocarpum, were assayed. Both species have amphistomatic leaves, anomocytic stomata, non-glandular and glandular trichomes, secretory cells present in the epidermis and mesophyll, bifacial structure, and the cuticle showing concentric striae around the stomata. Tunnel-type domatia were found in C. procumbens, at laminar base at the junction of the three principal veins on the adaxial surface. These domatia are interpreted as an apomorphic character for the genus and tribe within the Sapindaceae. In C. pterocarpum domatia are exceptionally present. This is the first record of adaxial domatia in Sapindaceae.
\end{abstract}

Key words: Cardiospermum, adaxial domatia, amphistomatic leaf, tunnel domatia, bifacial structure.

\section{INTRODUCTION}

The genus Cardiospermum L. comprises 14 species, three of which show pantropical distribution; they are herbaceous climbers, subshrubs with less frequency, or rarely rhizomatous hemicryptophytes. Cardiospermum occurs throughout the Neotropics, with the main centre of distribution in west-central Brazil. It belongs to the largely neotropical tribe Paullinieae (Sapindaceae), along with the genera Serjania Mill., Paullinia L., Urvillea Kunth, Houssayanthus Hunz., and Lophostigma Radlk. (subtribe Paulliniinae) and Thinouia Triana \& Planch. (subtribe Thinouiinae). Cardiospermum is the closest to Urvillea and they share numerous synapomorphic characters; however, usually, Cardiospermum has inflated capsules that differ from the non-inflated capsules of Urvillea.

The presence of leaf domatia on the adaxial face of Cardiospermum procumbens Radlk. encouraged us to perform this comparative study of the morphology and anatomy of this species and the related C. pterocarpum Radlk. Both species belong to section Cardiospermum (Sapindaceae-Paullinieae); they are closely related and partially sympatric. Cardiospermum procumbens is the only species of the tribe with simple leaves, and the junction of the three principal veins is prominent adaxially. It is endemic to Mato Grosso do Sul and grows in 'cerrado' vegetation. Cardiospermum pterocarpum has trifoliate leaves and its distribution is restricted to the centre and southeast of Brazil, eastern Paraguay and NE Argentina in the Corrientes province; it grows in 
both 'cerrado' and open vegetation. Both species are rhizomatous hemicryptophytes and have a creeping habit.

Domatia are hereditary structures that develop independently of mites or any other animal that utilizes them (Dottori, 1976; Tô Ngoc-Anh, 1996). Domatia have been recorded in 277 families and in almost 2000 species of angiosperms (Agrawal \& Karban, 1997). Gregory (1990), in a table that shows the occurrence of domatia in orders and families of dicotyledons, showed that Sapindaceae has the third highest number of species with domatia, which occur in 84 species.

Foliar domatia are often present on the lower surface in the axil of the basiscopic secondary nerves in different Sapindaceae genera (Adâmoli de Barros, 1961; Gregory, 1990; Ferrucci, 1996). Radlkofer (1931-1934) recognized their taxonomic value, although he did not apply the term domatium but only described their morphology. The Latin term 'domatium', which means small house, was applied to botany by Lundström in 1877, who defined it as a formation or transformation on plants adapted to the habitation of guests, whether animal or vegetable, which are of service to the host. These structures are classified according to their external morphology in the following types: tufts of hairs, sacs, pits or crypts, and revolute margin at the leaf base (Wilkinson, 1979).

Radlkofer (1890), in the treatment of the family Sapindaceae, presented a thorough morphological and anatomical study of the vegetative organs based on representative species of the family. More recent papers about leaf anatomy or related aspects of species of the tribe Paullinieae include an analysis of the foliar anatomy of Paullinia cupana var. sorbilis (Mart.) Ducke ('guaraná'; De Areia, 1966), while Valente et al. (1984a, b) studied the venation and foliar epidermis in species of Paullinia L., Thinouia Triana \& Planch., and Serjania Mill. of Rio de Janeiro. Acevedo-Rodríguez (1993) examined the foliar anatomy of Serjania.

In Cardiospermum, hairy tuft domatia were mentioned by Brouwer \& Clifford (1990) for C. corindum L. (as C. canescens Wall.) and C. grandiflorum Sw. (as C. grandiflorum forma hirsutum (Willd.) Radlk.). De Almeida-Ferraz \& Gonçalves Costa (1985) described the foliar anatomy of Paullinia carpopodea Cambess., including the only description of domatia available for Paullinieae.

The aim of this paper is to present a comparative analysis of the leaf morpho-anatomy of $C$. procumbens and $C$. pterocarpum, focused on the presence of domatia on the adaxial surface which represents a character of systematic importance in the genus, in the hope that this information will be useful in the phylogenetic studies of the tribe.

\section{MATERIALS AND METHODS}

Fresh samples fixed with FAA (Formol Acetic acid Alcohol), and dry ones previously rehydrated by boiling in water, were used for the anatomical research.

The present investigation was mainly based on light-microscope examinations. Leaf transverse and longitudinal sections were prepared according to standard techniques. Permanent microscope slides were made by dehydration through ethanol series and the pre-impregnation was carried out with a rinsing pre-impregnant (González \& Cristóbal, 1997). For infiltration in paraffin, the technique of Johansen (1940) was utilized, and the material was later embedded in 'Histoplast ${ }^{\circledR}$ '. Transverse sections $10-15 \mu \mathrm{m}$ thick 
of petiole, stipules and laminas from both species were made with a rotary microtome, and stained with Astra blue-safranin (Luque et al., 1996) before mounting them on synthetic Canada Balsam. Transverse sections of domatia were made from the angle formed by the secondary and middle veins to the distal end.

The venation was studied using leaf skeletons (Dilcher, 1974). The study of epidermical characters was performed by leaf clearing according to Dizeo de Strittmatter (1973) and safranin staining. The terminology mainly follows Hickey (1974). The stomatal index was obtained according to Salisbury (Wilkinson, 1979).

Observations and photographs were performed using a Wild M5 stereomicroscope and an Olympus BX 50F binocular microscope. Drawings were made using a camera lucida. The SEM micrographs were obtained with a JEOL 5800 LV scanning electron microscope operating at $20 \mathrm{KV}$. Preserved material was dehydrated and then immersed in $\mathrm{CO}_{2}$ for critical point drying before coating.

The voucher specimens are deposited in the Herbarium of the Instituto de Botánica del Nordeste (CTES):

Cardiospermum procumbens Radlk. - BRAZIL. Ferrucci 913; Ferrucci et al. 1313; Krapovickas \& Cristóbal 34518.

Cardiospermum pterocarpum Radlk. - ARGENTINA. Arbo et al. 893, 2193; Martínez

Crovetto 10315; Pedersen 4651. - BRAZIL. Archer \& Gehrt s.n.; Ferrucci et al. 1312, 1319; Macedo 1308. - PARAGUAY. Ferrucci et al. 656, 700, 929; Krapovickas \& Cristóbal 34277; Krapovickas \& Schinini 32570; Krapovickas et al. 13969, 46053; Pedersen 15037; Schinini \& Bordas 20198, 20382, 20504; Schinini \& Dematteis 33576; Schinini et al. 28120; Vanni et al. 241.

\section{RESULTS}

\section{Cardiospermum procumbens}

\section{Leaf morphology}

Stipules triangular-subulate, sometimes subfoliaceous, persistent; prominently vascularized. Petiole semi-terete or dorsiventral flattened, canaliculate, with two distinct wings. Blade simple, palmately-3-lobed, chartaceous, broadly obovate; base cuneate or cuneate-decurrent; apex mucronate; margin incised-dentate, with obtuse glandular teeth; epiphyll and hypophyll usually glabrous except principal veins; with three primary veins, venation actinodromous, more prominent on the epiphyll, intersecondary veins of composite type (Fig. 1a), areoles polygonal, randomly distributed with freely branched ending veinlets.

\section{Leaf anatomy}

Stipules surface - Stomatal index of the adaxial epidermis $8.6 \%$, of the abaxial epidermis $13.2 \%$.

Transverse section (Fig. 2d) - Adaxial and abaxial epidermis composed of large rounded cells, most of them with reddish cellular content; cuticle with epicuticular striae, thicker on the abaxial side; stomata small, $8.8-19.2$ by $9.4-16.8 \mu \mathrm{m}$, flush with surface 

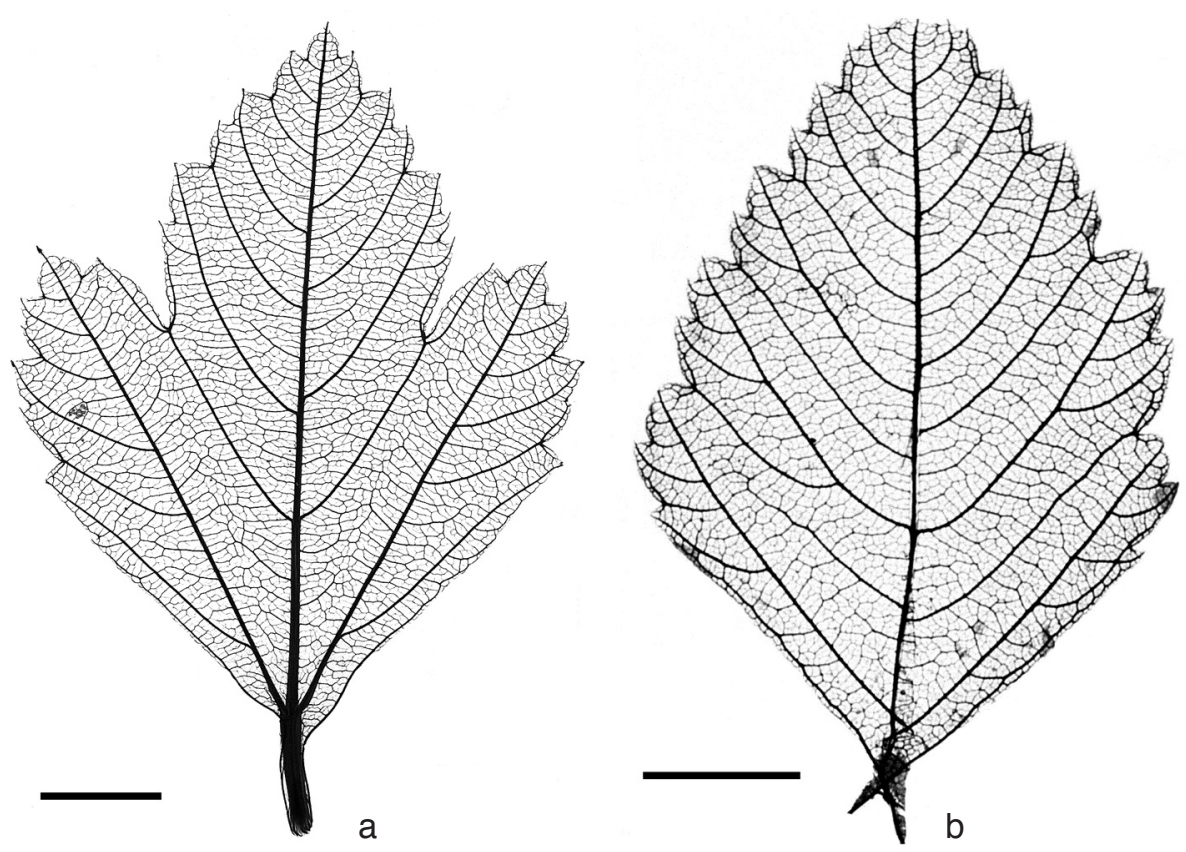

Fig. 1. Leaf architectural features. a. Leaf skeleton of Cardiospermum procumbens Radlk.; b. leaflet skeleton of $C$. pterocarpum Radlk. Scale bars: $\mathrm{a}, \mathrm{b}=1 \mathrm{~cm}$.

or raised; surface infrequent with simple and glandular hairs. Mesophyll homogeneous, chlorenchyma with small vascular bundles, idioblasts with reddish content abundantly present; midrib with closed collateral bundle, phloem with a cap of phloem fibres.

Petiole (Fig. 2c): Transverse section - Epidermal cells small, rectangular; beneath them tangential collenchyma present in an usually 1-3-layered continuous cylinder, these cells presenting chloroplasts, parenchyma on the inner side. Vascular tissue showing an earlier stage in activity of fascicular and interfascicular cambium. Cambial zone more or less semi-circular, separating external phloem from xylem, the internal phloem elements from the four or five strands where the xylem is well developed, with larger diameter than those of the external phloem. Pith composed of large and round parenchyma cells. Secretory cells, abundantly present, with reddish content, laticiferous, found mainly in the phloem (in longitudinal sections these cells are arranged in rows). Vascular tissue externally surrounded by a 3- or 4-layered ring of fibres. Isodiametric cells with simple rhomboidal crystals present on both sides of the fibres. On the adaxial side both wings provided with a bicollateral closed bundle, the latter surrounded by a sheath of fibres, chlorenchyma under epidermis.

Leaf blade surface - Both epidermises with unspecialized epidermal cells with straight anticlinal walls; small stomata of the anomocytic type may be located on the same level or slightly above the surface of the other epidermal cells (Fig. 3a, b); hairs 


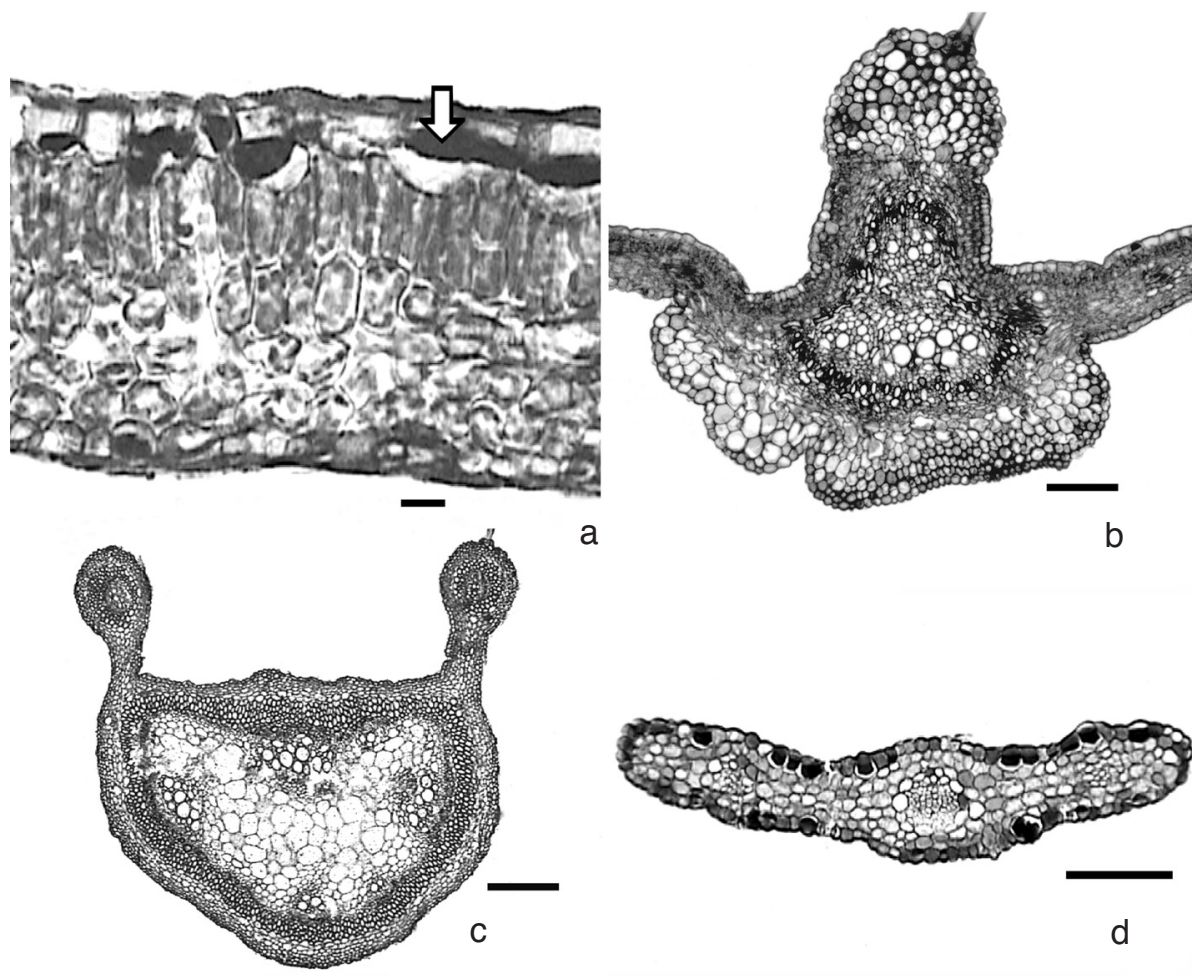

Fig. 2. LM micrographs of Cardiospermum procumbens Radlk. a. Transverse section of the leaf (arrow: secretory cell); b. transverse section of midrib; c. transverse section of petiole; $d$. transverse section of stipule. Scale bars: $\mathrm{a}=10 \mu \mathrm{m} ; \mathrm{b}, \mathrm{d}=100 \mu \mathrm{m} ; \mathrm{c}=200 \mu \mathrm{m}$.

sparse, simple, unicellular or uniseriate, of 2-6 cells, also procumbent glandular hairs with the base formed by 1 or 2 cells and the head with 4 or 5 cells (Fig. 3c-e); stomatal index 12-13\%; cuticular striae concentric to the stomata (Fig. 4a, b).

Transverse section - Lamina bifacial. Both epidermises uniseriate, adaxial epidermis with irregular cells and abundant larger secretory cells. Mesophyll (Fig. 2a) palisade tissue composed of 1 or 2 layers of rectangular cells interrupted by epidermal secretory cells; spongy tissue rather compact with isodiametric cells; collateral closed vascular bundles embedded in mesophyll or completely transcurrent by bundle sheath extensions of ground-tissue-like parenchyma; leaf margin with marginal vein and supplied with sclerenchyma. Abaxial epidermis with rectangular cells, smaller than those of the adaxial epidermis (Fig. 3f).

Midrib (Fig. 2b) usually projecting on both sides, especially adaxially; two open bicollateral bundles in the middle part of the lamina, the internal phloem scarce, one small bundle towards the adaxial face and the other one, larger, towards the abaxial face; sclerenchyma sheath of 3 or 4 layers of fibres, hardly lignified, surrounding the vascular system; 1 or 3 layers of angular collenchyma beneath both epidermises located 

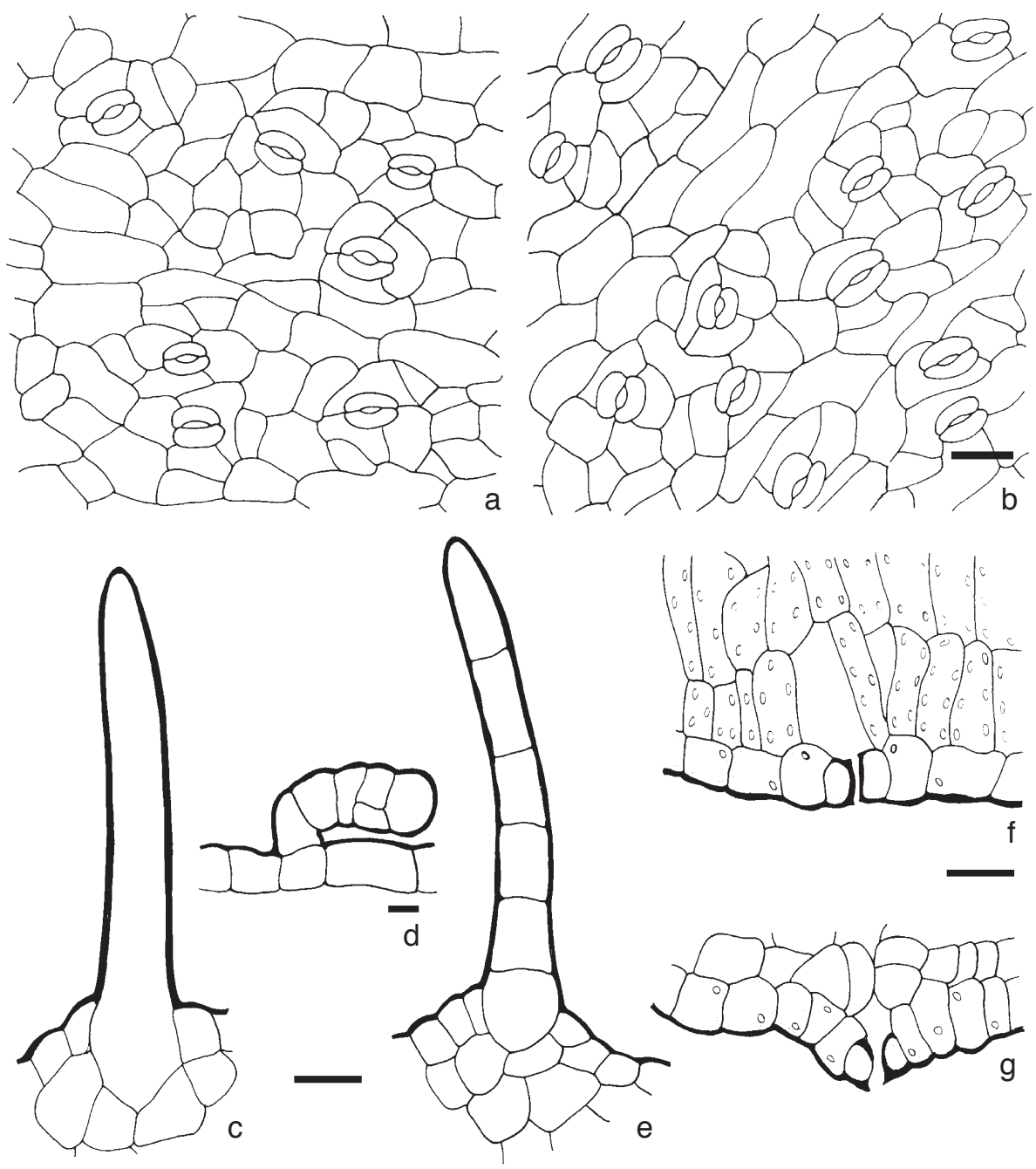

Fig. 3. Leaf features of Cardiospermum procumbens Radlk. a. Adaxial epidermis; b. abaxial epidermis; c. unicellular trichome; d. glandular trichome; e. uniseriate and multicellular trichome; f. transverse section of abaxial epidermis, showing the stomata; g. transverse section of domatium epidermis, showing the stomata. Scale bars: a \& b, c \& e, f \& $\mathrm{g}=10 \mu \mathrm{m} ; \mathrm{d}=100 \mu \mathrm{m}$.

inside parenchyma tissue idioblasts with reddish content, abundant in the phloem; parenchyma cells of the pith may be totally sclerified. Four vascular bundles at domatia level, three oriented to the abaxial face and one to the adaxial face.

Domatium morphology (Fig. 4c, d)

Always present on both sides of the midrib, located on the adaxial side of the leaf at the leaf base, in the angles formed by the junction of the three main veins, consid- 

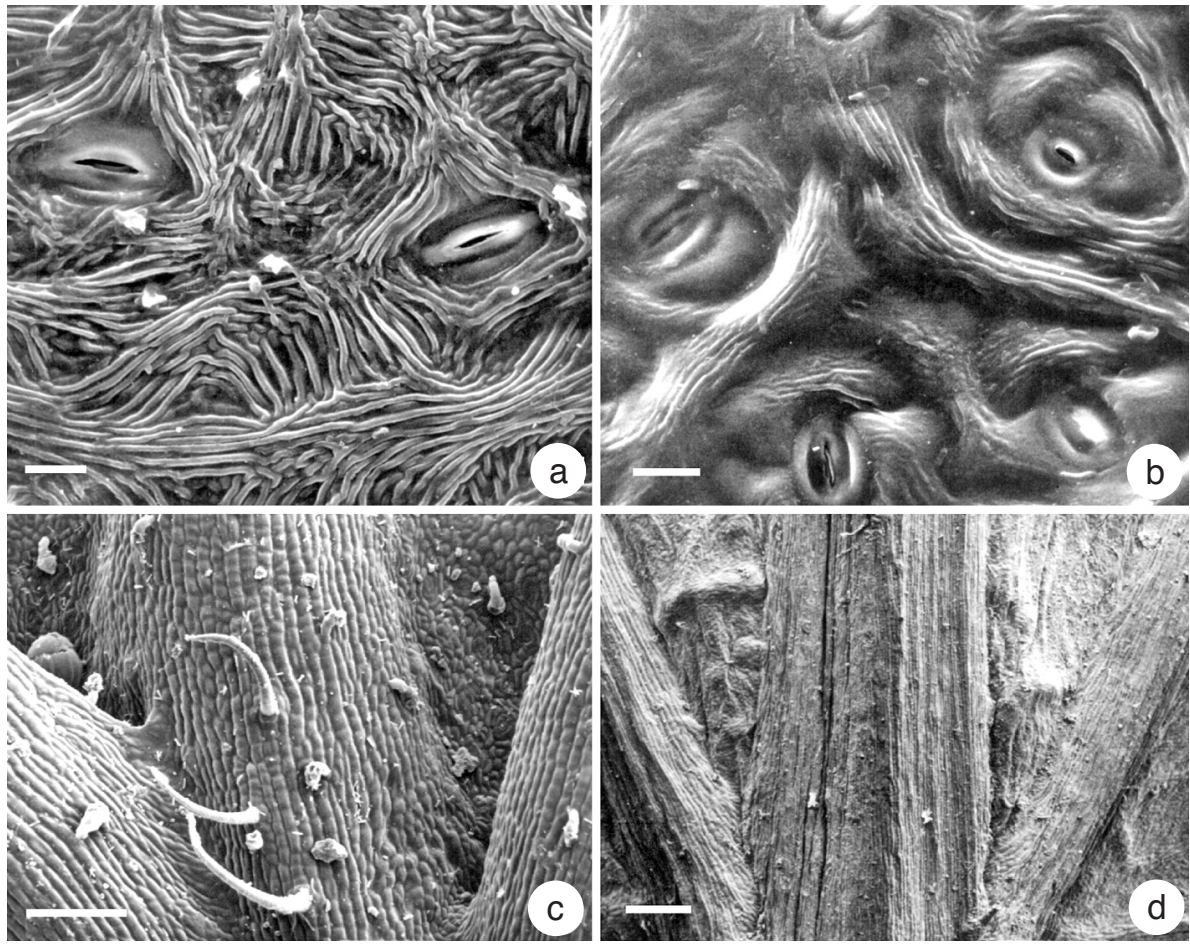

Fig. 4. Cardiospermum procumbens Radlk. SEM micrographs of the leaf surface. a. Adaxial epidermis; b. abaxial epidermis; c. domatia in the foliar base at the junction of the three principal veins on the leaf adaxial surface; d. abaxial epidermis showing the slight dome on the lower surface of the lamina at domatia level. LM micrographs of the leaves. Scale bars: $\mathrm{a}, \mathrm{b}=10 \mu \mathrm{m} ; \mathrm{c}=100 \mu \mathrm{m}$; $\mathrm{d}=200 \mu \mathrm{m}$.

ered primary-axillary because of their position (Stace, 1965). Each domatium with an opening of variable size at the end of a tunnel running through the mesophyll. Each structure projecting inwards on the adaxial side with a slight dome on the lamina lower surface.

\section{Domatium anatomy}

At the proximal end of the domatium there is a small group of cells, compactly disposed and intensely coloured, clearly different in size from the rest of the parenchymatous cells (Fig. 5a).

In a proximal upper zone, the group of cells is separated by dissolution of the middle lamella and delimited by a longitudinally extended orifice. The cells forming the domatium epidermis remain small. The orifice corresponds to the beginning of a tunnel running through mesophyll tissues. Surrounding the domatium epidermis are 2 or 3 layers of compactly arranged parenchymatous cells (Fig. 5b).

In the mid-point, with larger channel amplitude, two parts of domatium can be distinguished, the floor and the roof (Penzig \& Chiabrera, 1903). Tissue beneath the floor 

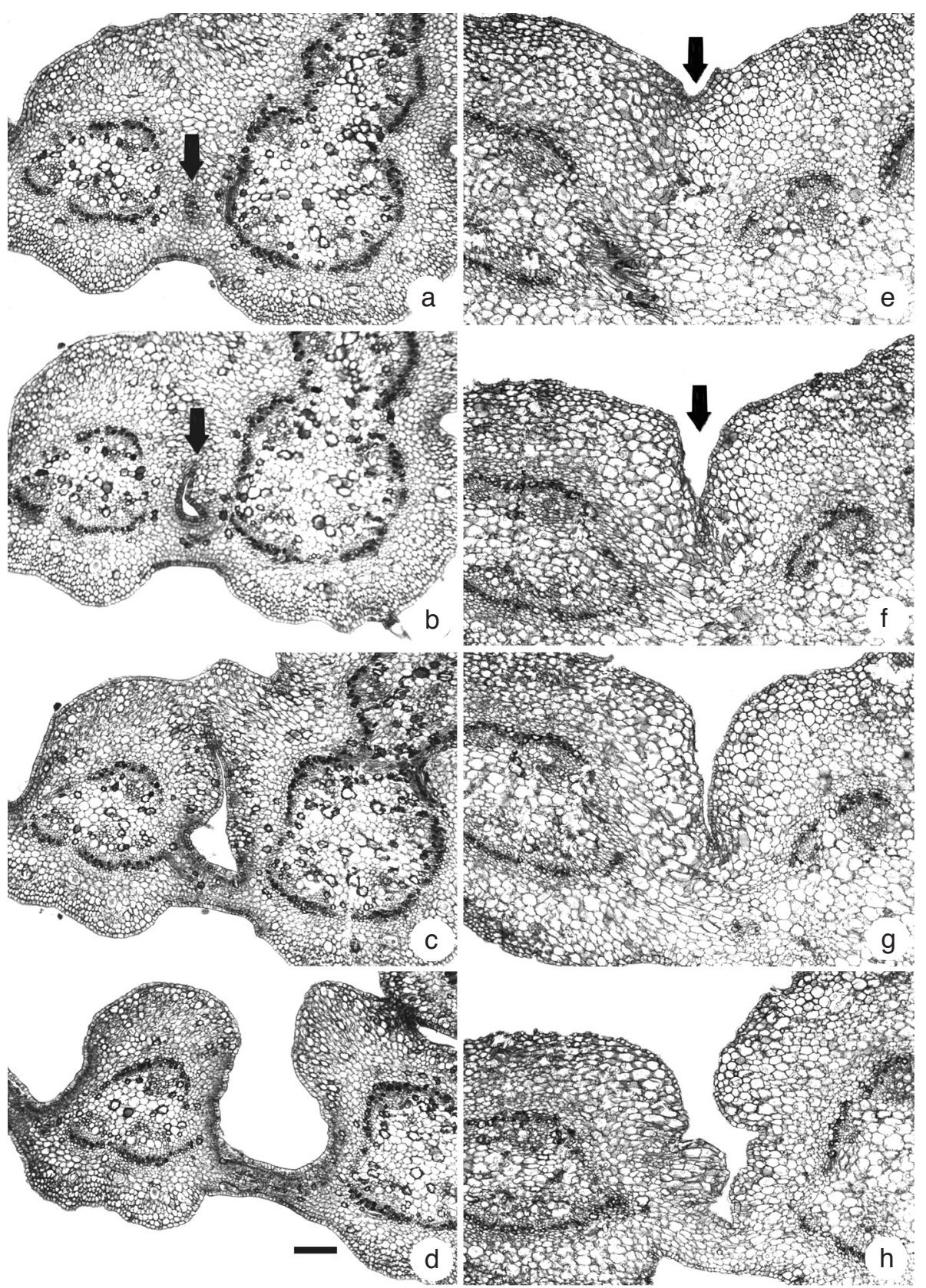

Fig. 5. Cardiospermum procumbens Radlk. Light micrographs of transverse sections of the domatium. a. Proximal zone of the domatium showing a group of small cells clearly different from the neighbouring cells; b. slightly distal section, showing an orifice delimited by the domatium epidermis; c. mid-zone of the domatium showing both parts of the domatium, the floor and the roof; d. distal zone of the domatium, the tunnel is open to the exterior; $\mathrm{e}-\mathrm{h}$. sequence from proximal to the distal zone showing an open pit-tunnel delimited by the midrib and the lateral vein. Scale bar $=100 \mu \mathrm{m}$. 
rather compact, a first layer with erect cells and the other layers with isodiametric ones, secretory cells also frequently observed, ground tissue over the roof is parenchyma, also with some secretory cells (Fig. 5c).

At the most distal zone, the tunnel is opened to the exterior, forming an important concavity corresponding to the domatium floor. Roof separated in two voluminous structures belonging to the midrib and the lateral vein, respectively. The inner part covered by the domatium epidermis (Fig. 3g, 5d), with stomata and simple hairs.

In other leaves of the same plant, the domatium tunnel opens to the exterior without forming an orifice in the inner part of the domatium; it is an opened pit delimited by the midrib and the lateral vein (Fig. $5 \mathrm{e}-\mathrm{h}$ ).

\section{Cardiospermum pterocarpum}

\section{Leaf morphology}

Stipules similar to C. procumbens. Petiole dorsiventral flattened, canaliculate, bicanaliculate or margined; petiolules frequently winged. Leaf blade trifoliate, leaflets ovate or wide-ovate, pinnatifid, pinnately parted or pinnatisect, base cuneate or cuneatedecurrent, apex mucronate, margin incised-dentate, with 2-4 incisions, teeth obtuse, with apical glands, glabrate or puberulent; venation prominent, pinnate, craspedodromous mixed; areoles similar to C. procumbens but comparatively smaller (Fig. 1b).

\section{Leaf anatomy}

Anatomical characters of the lamina, petiole, stipules and domatium are similar to those of $C$. procumbens.

In the lamina are abundant, large secretory cells with reddish content in the epidermis and mesophyll, also common in the petiole epidermis and parenchyma. Stomatal index of the adaxial epidermis $11.3 \%$, of the abaxial epidermis $14 \%$. The pit-tunnel type of domatium occurs exceptionally in adult leaves.

\section{DISCUSSION}

Cardiospermum procumbens and C. pterocarpum are closely related; they are basically distinguished by the leaf type, simple in the first species and compound in the second one; in addition to the characteristic domatium of $C$. procumbens. These species share the same habit, foliar structure and epidermal characters.

Both species have amphistomatic leaves, an infrequent character in Sapindaceae, where the leaves are hypostomatic or when amphistomatic, they have a few stomata mainly near the veins. In Cardiospermum, only C. tortuosum Benth., C. procumbens, C. pterocarpum, C. anomalum Cambess., and C. cuchujaquense Ferrucci \& Acev.Rodr. have amphistomatic leaves; they all grow in xerophytic habitats (Ferrucci, 2000). Solereder (1908) mentions stomata in both surfaces only for rare species of different genera of the family.

In Cardiospermum, the cuticle generally presents striae, marked in the epiphyll and less notable in the hypophyll. In most species, the striae radiate from the stomata, the 
presence of concentric striae rings around the stomata, as occurring in C. procumbens and $C$. pterocarpum, is rare (Ferrucci, 2000).

The bifacial lamina agrees with the treatment of Metcalfe \& Chalk (1957) for most species of the genus. Radlkofer (1931-1934) reported leaves wholly or partly centric for Cardiospermum tortuosum and C. spinosum Radlk., the latter included as a synonym of C. tortuosum (Ferrucci, 2000). Although the anatomical study of C.tortuosum showed that the leaf is bifacial, prismatic cells occasionally interrupt the spongy tissue; in this case the leaf structure would be interpreted as isobilateral (Ferrucci, 2000). The presence of secretory cells in both studied species mesophyll represents a usual character for the family (Solereder, 1908).

It is interesting to point out that the larger vascular strands present in the petiole, as well as the strands of the blade midrib, are bicollateral. In the available literature, this character has been reported only for Paullinia carpopodea Cambess. (De AlmeidaFerraz \& Gonçalves Costa, 1985). The petiole and midrib vascular tissue has always been interpreted as collateral; including the recent report on foliar anatomy of tribe Harpullieae (Buijsen, 1995). The presence of vascular bundles in the wings of the petiole in both species agrees with Metcalfe \& Chalk (1957), who mentioned additional cortical bundles for Paullinia cupana Kunth.

These domatia, which occur frequently on the adaxial surface of $C$. procumbens and occasionally in C. pterocarpum, are the first record in Paullinieae. So far, the only citation about domatia on the adaxial face corresponds to Timonius timon (Spreng.) Merr. (Rubiaceae), which shows domatia on both faces located in the vein axils (O'Dowd \& Willson, 1989).

The type of domatium present in C. procumbens agrees with the tunnel-type described by Brouwer (1985). In the Paullinieae, hairy tuft domatia are cited for Paullinia imberbis Radlk. (Adâmoli de Barros, 1961); Lophostigma schunkei (Acev.-Rodr.) Acev.-Rodr. (as Serjania schunkei Acev.-Rodr.) (Acevedo-Rodríguez, 1988) and for numerous species of Serjania (Acevedo-Rodríguez, 1993). De Almeida-Ferraz \& Gonçalves Costa (1985) described pocket-like domatia (as 'marsupiform') on the proximal 2/3 of the hypophyll of $P$. carpopodea Cambess.

The taxonomic value of domatia was underestimated by Jacobs (1965), who recommended great caution with the domatia reports in the literature. This position was refuted by Van Steenis (1968), who considered them as useful as any other vegetative or reproductive diagnostic character. The occurrence and type of domatia have been utilized to characterize genera and to distinguish species within them (Wilkinson, 1979; Brouwer, 1985). Radlkofer (1931-1934) used this character to distinguish species, e.g. in Matayba Aubl.

For some authors, the occurrence of domatia is restricted to woody dicotyledons, primarily from tropical and humid subtropical regions (O’Dowd \& Willson, 1989); in C. procumbens, however, the only slightly woody organ is the rhizome.

As a corollary, we can infer that, from an evolutionary point of view, C. procumbens would be more derived relative to $C$. pterocarpum, considering the simple blade as a reduction and the presence of domatia in the adaxial side of the leaf as an apomorphic character for the genus and the tribe within the family. Finally, the presence of concentric striae around the stomata in these two species would represent a synapomorphy for the genus (Ferrucci, 2000). 


\section{ACKNOWLEDGEMENTS}

We are indebted to Dr. Gabriel Bernardello for very helpful comments on the manuscript. The authors are also grateful to Dr. Orlando Popoff and Eng Carolina Peichoto for assistance with the digitation of images, to Ernestina Galdeano for improving the English version, and anonymous reviewers for the useful comments. Financial support for the second author was provided by the Universidad Nacional del Nordeste (PI 08/03) and by the Consejo Nacional de Investigaciones Científicas y Técnicas (CONICET) (PIP 0556/98).

\section{REFERENCES}

Acevedo-Rodríguez, P. 1988. Novelties in Serjania (Sapindaceae). Brittonia 40: 283-289.

Acevedo-Rodríguez, P. 1993. Systematics of Serjania (Sapindaceae) part I: A revision of Serjania sect. Platycoccus. Mem. New York Bot. Gard. 67: 1-93.

Adâmoli de Barros, M. 1961. Ocorrência das domácias nas angiospermas. Anais Esc. Super. Agric. 'Luiz de Queiroz' 18: 113-130.

Agrawal, A. \& R. Karban. 1997. Domatia mediate plant-arthropod mutualism. Nature 387: 562563.

Brouwer, Y.M. 1985. Domatia - morphology, anatomy and biological significance. PhD thesis, University of Queensland.

Brouwer, Y.M. \& H.T. Clifford. 1990. An annotated list of domatia bearing species. Notes Jodrell Lab. 12: 1-33.

Buijsen, J.R.M. 1995. Leaf anatomy of Harpullia, Majidea, and Conchopetalum (Sapindaceae). Blumea 40: 345-361.

De Almeida-Ferraz, C.L. \& C. Gonçalves Costa. 1985. Paullinia carpopodea Camb. (Sapindaceae). Anatomia foliar. Rodriguésia 37, 62: 79-90.

De Areia, C.A. 1966. Anatomia da fôlha do guaraná, Paullinia cupana var. sorbilis (Mart.) Ducke (Sapindaceae). Rodriguésia 25: 297-312.

Dilcher, D.L. 1974. Approaches to the identification of angiosperm leaf remains. Bot. Rev. (Lancaster) 40:1-157.

Dizeo de Strittmatter, C.G. 1973. Nueva técnica de diafanización. Bol. Soc. Argent. Bot. 15: $126-129$.

Dottori, N.M. 1976. Morfología foliar en Celtis tala y C. pallida con especial referencia a los domacios. Kurtziana 9: 63-80.

Ferrucci, M.S. 1996. Urvillea paucidentata y Serjania adenophylla (Sapindaceae), dos especies nuevas de Mato Grosso, Brasil. Bonplandia (Corrientes) 9: 19-23.

Ferrucci, M. S. 2000. Revisión de los géneros Cardiospermum y Urvillea para el neotrópico (Sapindaceae). Tesis Doctoral. Universidad Nacional de Córdoba, Argentina.

González, A.M. \& C.L. Cristóbal. 1997. Anatomía y ontogenia de semillas de Helicteres Lhotzkyana (Sterculiaceae). Bonplandia (Corrientes) 9: 287-294.

Gregory, M. 1990. Additional records of occurrence of domatia. Notes Jodrell Lab. 12: 34-50.

Hickey, L.J. 1974. Clasificación de la arquitectura de las hojas de Dicotiledóneas. Bol. Soc. Argent. Bot. 16: 1-26.

Jacobs, M. 1965. Domatia. Fl. Males. Bull. 4, 20: 1272-1273.

Johansen, D. A. 1940. Plant microtechnique. McGraw-Hill Book Company, Inc., New York.

Lundström, A. N. 1887. Pflanzenbiologische Studien II. Die Anpassungen der Pflanzen an Thiere. Nova Acta Regiae Soc. Sci. Upsal. 3, 13: 1-88.

Luque, R., H.C. Sousa \& J.E. Kraus. 1996. Métodos de coloração de Roeser (1972) - modificado E. Kropp (1972), visando a substituição do azul de astra por azul de alcião 8GS ou 8GX. Acta Bot. Bras. 10: 199-212.

Metcalfe, C.R. \& L. Chalk. 1957. Anatomy of the dicotyledons. Vol. 1. Clarendon Press. Oxford.

O'Dowd, D. J. \& M.F. Willson. 1989. Leaf domatia and mites on Australasian plants: ecological and evolutionary implications. Biol. J. Linn. Soc. 37: 191-236. 
Penzig, O. \& C. Chiabrera. 1903. Contributo alla conoscenza delle piante acarofile. Malpighia 17: 429-487.

Radlkofer, L. 1890. Ueber die Gliederung der Familie der Sapindaceen. Sitzungsber. Math-Phys. Cl. Königl. Bayer. Akad. Wiss. München 20: 105-379.

Radlkofer, L. 1931-1934. Sapindaceae. In: A. Engler, Das Pflanzenreich 4, 165: 1-1539. Engelmann, Leipzig.

Solereder, H. 1908. Systematic anatomy of the dicotyledons. (Translated by L.A. Boodle \& F.E. Fritsch.) Vol. 1. Clarendon Press, Oxford.

Stace, C.A. 1965. Cuticular studies as an aid to plant taxonomy. Bull. Brit. Mus. (Nat. Hist.), Bot. 4: $1-78$.

Tô Ngoc-Anh. 1966. Sur la structure anatomique et l'ontogénèse des acarodomaties et les interprétations morphologiques qui paraissent s'en dégager. Adansonia 2, 6: 147-151.

Valente M da C., J.F.A. Baumgratz \& N.M.F. da Silva. 1984a. Sapindáceas do Estado do Rio de Janeiro II - Nervação e epiderme foliar do gênero Serjania Plum. ex Schum. Rodriguésia 36, 61: $33-48$.

Valente M da C., N.M.F. da Silva \& J.F.A. Baumgratz. 1984b. A nervação foliar das Sapindáceas do Estado do Rio de Janeiro I - Gênero Paullinia L. e Thinouia Planch. et Triana. Rodriguésia 36, 60: 17-22.

Van Steenis, C.G.G.J. 1968. Occurrence of domatia as a systematic character. Fl. Males. Bull. 5, 22: $1568-1570$.

Wilkinson, H.P. 1979. The plant surface (mainly leaf). In: C.R. Metcalfe \& L. Chalk, Anatomy of the Dicotyledons. Vol. 1, 2nd ed.: 97-165. Oxford. 